\title{
A sample study on nitrogen removal from polluted streams by using hybrid natural wastewater treatment systems
}

\author{
Tunçsiper B. ${ }^{*}$ \\ Nigde Omer Halisdemir University, Department of Environmental Engineering, Nigde, 51240, Turkey \\ Received: 17/04/2018, Accepted: 29/07/2018, Available online: 26/09/2018 \\ *to whom all correspondence should be addressed: e-mail: tuncsiperb@ohu.edu.tr \\ https://doi.org/10.30955/gnj.002715
}

\begin{abstract}
The ecological structure and function of the water reservoirs deteriorate dramatically because of streams fed by the excess nitrogen-containing wastewater. To protect the water reservoirs from polluted streams, structures such as natural wastewater treatment (NWT) systems to be created inside or outside streams may be a most suitable and economical solution method to overcoming the problem. In this study, a hybrid NWT system was installed to remove nitrogenous pollutants in Karasu creek (Nigde city, Turkey) in 2014. The system built near the creek consisted of feeding basin (FB), settlement basin (SB), free water surface-constructed wetland (FWS-CW), and overland flow (OF) system respectively. Despite quite high nitrogen loading rates, the system managed to reduce $\mathrm{NH}_{4}{ }^{+}-\mathrm{N}$ from average $29 \mathrm{mg} / \mathrm{L}$ to $12 \mathrm{mg} / \mathrm{L}$ and TN from $44 \mathrm{mg} / \mathrm{L}$ to $19 \mathrm{mg} / \mathrm{L}$ with an average removal efficiency of $57 \%$. Results revealed that hydraulic and nitrogen loading rate, temperature and seasonal variation, $\mathrm{BOD} / \mathrm{TKN}$ ratio, hydraulic residence time (HRT), and the use of the filter material were effective on nitrogen removal. The results suggest that the hybrid NWT systems can be used as a low-cost wastewater treatment alternative to improve water quality in streams contaminated by nitrogenous pollutants in the similar areas.
\end{abstract}

Keywords: Constructed wetland, overland flow, stream water purification, wetland hydrology.

\section{Introduction}

Excessive nitrogenous compounds (especially nitrates) coming surface water sources from streams and surface flows have been bearing a significant threat element because of their role in eutrophication, their effect on the oxygen content, excessive plant growth which in turn stimulates the biogeochemical cycles of surface waters, and their toxicity to aquatic invertebrate and vertebrate species (Kadlec and Wallace, 2009; Aguiar et al., 2011; Li et al., 2011; Zhang et al., 2011). To protect surface water sources against the negative effects of nitrogen pollution, nitrogenous compounds in primarily streams or creeks should be brought under control. For these reasons, natural wastewater treatment (NWT) systems such as constructed wetland (CW) and overland flow (OF) systems have been used successfully as alternative in purification of polluted streams and wastewater treatment containing different types of pollutants at many studies worldwide (Reed et al., 1995; Crites et al., 2000; Crites et al., 2006; Kadlec and Wallace, 2009; Kim et al., 2014; Lai, 2014; Li et al., 2014; Morató et al., 2014; Tu et al., 2014; Lin et al., 2015).

The majority of the researches conducted to prevent nitrogen pollution in streams were focused on their only restoration by removing concrete and filling materials or the improvement of their water quality using a separate wastewater treatment system such as the CW systems. Many researchers declared the results of studies on the improvement of stream water quality by using a separated wastewater treatment system. For example, Zheng et al. (2014) evaluated treatment performances of combined CW systems constructed in the flooded land near the confluence of the Zaohe stream to the Weihe stream in the west suburb of Xi'an (northwestern megacity in China) for control of streams' water pollution. Zhou and Hosomi (2008) examined nitrogen transformations on the $\mathrm{CW}$ systems constructed to improve the water quality of the Sannogava stream entering the Lake Kasumigaura in Japan. Tang et al. (2013) examined nitrogen removal performance of the $\mathrm{CW}$ systems (500 m long, $20 \mathrm{~m}$ wide) installed near Qilihai Wetland in Tianjin to treat polluted stream water from the Chaobaixin stream.

On the other hand, instead of using a separate wastewater treatment system, the idea of improving water quality by restoring the streams have gained more importance in the past decade (Nakamura et al., 2006; Søndergaard and Jeppesen, 2007). Most of the restoration studies included activities to remove the filling materials and recover the degraded vegetation and plant diversity (Nishihiro et al., 2006). For example, Hunt et al. (1999), Stone et al. (2003), Cui et al. (2013) applied in-stream wetlands in order to restore or remediate the polluted streams. Kadlec and Hey (1994) illustrated the potential of the CW systems to control nitrogen pollution in the Des Plaines River Wetlands Demonstration Project. 
Mayer et al. (2013) evaluated the effects of the Minebank Run stream restoration (Baltimore, Maryland) on nitrogen removal. In addition, Gabriele et al. (2013) studied the effects of channel reconfiguration and riparian reforestation on the nitrogen retention capacity of eutrophic agricultural headwater streams. However, unfortunately, the majority of studies declared above have not focused on a comprehensive water quality changes in streams restored.

To prevent contamination of surface water sources primarily streams that feed and pollute them is necessary to bring under control or rehabilitate. Four main rehabilitation objectives for polluted streams here are identified: (1) natural flood control and correspondingly reduced maintenance costs; (2) enhanced aesthetics and recreational uses; (3) enhanced aquatic habitat; and (3) improved water quality (Task Force to Bring Back the Don, 1991; Royal Commission, 1992).

Akkaya reservoir has become almost unusable due to excessive pollution. Karasu creek is most important pollution source that feeds and also pollutes Akkaya reservoir. To overcome the problem of nitrogen pollution in the reservoir, initially, the creek must be stabilized or cleaned using a separate treatment system such as the $\mathrm{CW}$ systems. Secondly, instead of only the restoring the polluted creek, as an alternative, it can be converted into a NWT system, and its water quality can be improved.

For these purposes, a hybrid NWT system was installed on the edge of over polluted Karasu creek to reduce nitrogen pollution and improve water quality in the creek. The prototype system was planned in a manner appropriate to the creek' native structure and hydraulic conditions. The main objective of this paper is to evaluate the ability of the hybrid NWT systems to remove nitrogenous compounds $\left(\mathrm{NH}_{4}{ }^{+}-\mathrm{N}, \mathrm{NO}_{3}{ }^{-}-\mathrm{N}, \mathrm{N}\right.$ org, TN) under different environmental and hydraulic conditions.Settlement Basin (SB), Free Water Surface Constructed Wetland (FWS-CW) and Overland Flow (OF) system was used in series in the hybrid system, respectively. This study presents only the nitrogenous compound's removal-related part of the TUBITAK (The Scientific and Technical Research Council of Turkey) project.

\section{Material and methods}

\subsection{Studied site description}

Akkaya reservoir is an important source of irrigation water for Nigde city and especially Bor district and is highly polluted by point and non-point pollution sorurces. The most important point sources that threaten the reservoir are the effluents of wastewater treatment plant of the organized industrial zone (OIZWTF) and Nigde university (NUWTF), and Karasu creek that receives undertreated effluents of the wastewater treatment plant of Nigde municipality (NMWTF). The creek is also under the influence of surface water draining from agricultural fields, quarry, and lime quarry-pit. Although the NMWTF that treats wastewater of about 120000 populations, it is often not very well operated, in large part of pollutants reach Akkaya reservoir via the creek. Figure 1 shows the location of the hybrid NWT system and over-polluted Karasu creek, and pollutant sources (see features denoted $1,2,3$, and 4) that pollute Akkaya reservoir. The creek has an about $27 \mathrm{~km}$ long within the borders of Nigde City, and it is poured into Akkaya reservoir. The NWT system was located on the edge of the creek, and in a region at the coordinates- $37^{\circ} 56^{\prime} 23.20^{\prime \prime} \mathrm{N}$ and $34^{\circ} 39^{\prime} 13.05^{\prime \prime} \mathrm{E}$ of Nigde City, Turkey.

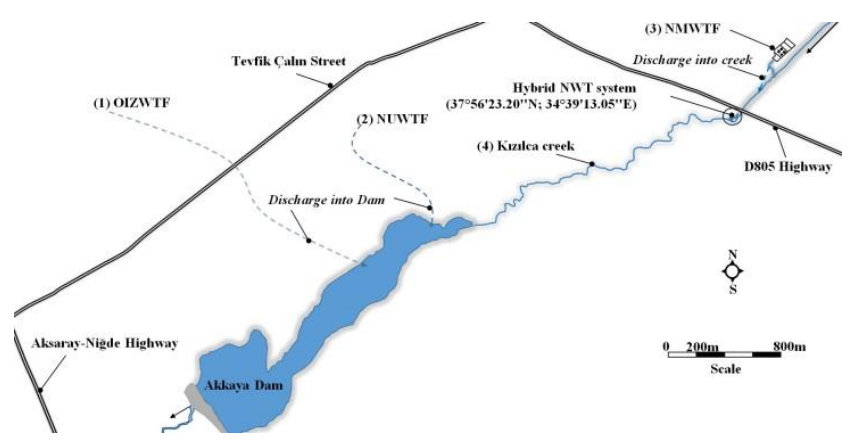

Figure 1. Location of the hybrid NWT system and the study site

\subsection{System design}

The hybrid NWT system was combined with the SB, the FWS-CW with filter material, and the OF system. The system generally consists of four stages. The first stage comprises a feeding basin (FB), the second one comprises the SB system, the third one comprises the FWS-CW system, and the fourth one comprises the OF system, respectively. The simplified flow diagram of the NWT system is shown in Figure 2.

The FB system that was designed for receiving of the water from the creek. The main function of the system was to prevent the subsequent the SB system from clogging.

The SB system was designed to reduce the high nitrogencontaining solid matter load on the FWS-CW system and thus increase system's treatment efficiency.

The FWS-CW system, which was best suited to high hydraulic loading rates (HLRs), have been widely used to remove especially nitrogenous and carbonaceous compounds, phosphorus, and metals, among other constituents, from wastewater (Reed et al., 1995; Crites and Tchobanoglous, 1998; USEPA, 1999). Therefore, the FWS-CW system was designed in order to be able to remove especially nitrogenous compounds in outflows of the SB. It was designed S-shaped in a manner to represent the convoluted structure of the creek. It was divided into 7 regions based on its twist points. In order to further improve the removal efficiency of nitrogenous compounds, in April 2015, twist places of the FWS-CW system was equipped with a filter layer that serves as a biofilter. Grain diameter of gravel material used for the filter layer ranges 0.8 to $6.3 \mathrm{~cm}$. The total volume of gravel used in the system is approximately $0.6 \mathrm{~m}^{3}$. The system was planted with the young shoots of Phragmites communis (macrophytes) growing in the creek edge. The OF system, which was consisted of washed sand in a 
depth of about $5 \mathrm{~cm}$, was designed to be able to provide an extra nitrogen removal in the outflows of the FWS-CW system. It was planted with italian ryegrass. Because the NWT system was planned in a manner appropriate to the creek' native structure, it was not made any barrier or drainage canal at the edge of the system in order to prevent runoff.

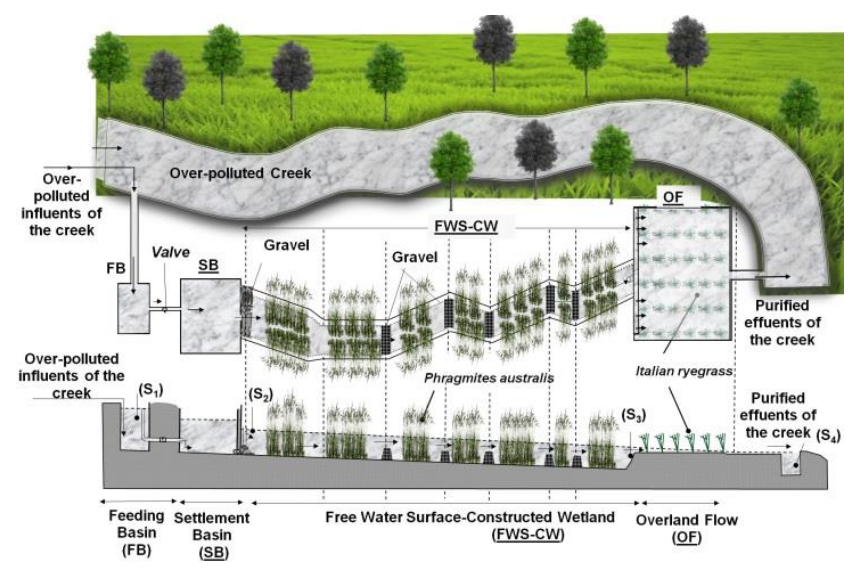

Figure 2. Schematic diagram of the hybrid NWT system $\left(\mathrm{S}_{1}, \mathrm{~S}_{2}, \mathrm{~S}_{3}, \mathrm{~S}_{4}\right.$ are sampling locations)

The measured hydraulic and physical properties of the existing stages in the NWT system were summarized in Table 1. The total length of the hybrid system is about $57 \mathrm{~m}$. The total water volume of the system is approximately $14.5 \mathrm{~m}^{3}$. In the FWS-CW system, the volume occupied by the filter material and emergent plants is approximately $1 \%$ and $19 \%$, respectively. To calculate the porosity of the washed filter material, firstly it was filled to an empty tank, and then the water was poured into the tank until it reaches the top of the filter material. Thus, the volume occupied by the water, that is, the porosity was calculated as about 0.53 .

\subsection{System operation}

The hybrid system was established in August 2014 and operated for an operation period of approximately 18 months. The first sampling on the system was carried out in October 2014. During the study period, the system was directly fed with part of the polluted creek.

\subsection{Sampling and analysis}

Water samples were taken and analyzed bimonthly or monthly from 2014 to 2016 to evaluate the effectiveness of the hybrid NWT system on nitrogen removal and water quality improvement in Karasu creek. Samples were collected from four sampling locations including $S_{1}$ (influent of the SB system), $S_{2}$ (effluent of the SB system or influent of the FWS-CW system), $\mathrm{S}_{3}$ (effluent of the FWS-CW system or influent of the OF system), and $\mathrm{S}_{4}$ (effluent of the OF system). Temperature, dissolved oxygen (DO), conductivity, and $\mathrm{pH}$ were measured in situ with a multi-parameter probe (SM 4500- $\mathrm{H}^{+}$). Total Kjeldahl-nitrogen (TKN), ammonium-nitrogen $\left(\mathrm{NH}_{4}{ }^{+}-\mathrm{N}\right)$, nitrate-nitrogen $\left(\mathrm{NO}_{3}^{-}-\mathrm{N}\right)$, organic-nitrogen (Norg.), biochemical oxygen demand (BOD) were analyzed as described in Standard Methods (APHA, 1998) (Table 2).

Table 1. Specifications of the existing stages in the hybrid system

\begin{tabular}{ccccccccc}
\hline & $\begin{array}{c}\text { Base } \\
\text { width }\end{array}$ & $\begin{array}{c}\text { Surface } \\
\text { width }\end{array}$ & $\begin{array}{c}\text { Cross-sectional } \\
\text { area }\end{array}$ & $\begin{array}{c}\text { Surface } \\
\text { area }\end{array}$ & Length & $\begin{array}{c}\text { Aspect } \\
\text { ratio }\end{array}$ & $\begin{array}{c}\text { Water } \\
\text { volume }\end{array}$ & Average water depth \\
\cline { 2 - 8 } & $(\mathbf{m})$ & $(\mathbf{m})$ & $\left(\mathbf{m}^{2}\right)$ & $\left(\mathbf{m}^{2}\right)$ & $(\mathbf{m})$ & $(\mathbf{m} / \mathbf{m})$ & $\left(\mathbf{m}^{3}\right)$ & 0.800 \\
\hline FB & 0.8 & 0.8 & 0.640 & 1.52 & 1.90 & $0.8 / 1.90$ & 1.216 & 0.700 \\
\hline FB & 1.6 & 1.6 & 1.120 & 4.08 & 2.55 & $1.6 / 2.55$ & 2.856 & 0.340 \\
\hline FWS-CW2 & 0.6 & 1.0 & 0.076 & 5.00 & 5.00 & $1.0 / 5.00$ & 0.380 & 0.380 \\
\hline FWS-CW3 & 0.6 & 1.0 & 0.080 & 5.00 & 5.00 & $1.0 / 5.00$ & 0.400 & 0.400 \\
\hline FWS-CW4 & 0.6 & 1.0 & 0.444 & 4.00 & 4.00 & $1.0 / 4.00$ & 1.776 & 0.420 \\
\hline FWS-CW5 & 0.6 & 1.0 & 0.448 & 5.00 & 5.00 & $1.0 / 5.00$ & 2.240 & 0.440 \\
\hline FWS-CW6 & 0.6 & 1.0 & 0.452 & 3.00 & 3.00 & $1.0 / 3.00$ & 1.356 & 0.460 \\
\hline FWS-CW7 & 0.6 & 1.0 & 0.420 & 5.00 & 5.00 & $1.0 / 5.00$ & 2.100 & 0.300 \\
\hline OF & 5.0 & 5.0 & 0.176 & 80.0 & 16.0 & $5.0 / 16.0$ & 0.880 & 0.011 \\
\hline
\end{tabular}

\subsection{Removal rate constants}

Different models were used to calculate removal rate constants in streams in the literature (Birgand et al., 2007). Majority of researches modeled the change of removal rate based on retention time, temperature, inflow, and outflow concentrations by using volume or area based first-order kinetics (Kadlec and Knight, 1996; Birgand et al., 2007; Kadlec and Wallace, 2009). In this study, practically, volume-based first-order kinetics was used to calculate nitrogen removal rate constants $\left(k_{20}\right)$.
The values of $k_{20}$ were calculated based on the average inflow and outflow values collected at different periods at the same temperature and hydraulic residence time (HRT) (Kadlec and Knight, 1996);

$$
\mathrm{C}_{\mathrm{e}}-\mathrm{C}^{*} / \mathrm{C}_{\mathrm{i}}-\mathrm{C}^{*}=\exp \left(-\mathrm{K}_{\mathrm{T}} \mathrm{t}\right)
$$

where $C_{i}$ and $C_{e}$ are mean influent and effluent and concentrations $(\mathrm{mg} / \mathrm{L}), \mathrm{C}^{*}$ is background concentration $(\mathrm{mg} / \mathrm{L})\left(\mathrm{C}^{*} \approx 0\right), \mathrm{K}_{\mathrm{T}}$ is the temperature-dependent rate 
constant (1/day) and it equals $k_{20} \theta^{T-20}$ (where $k_{20}$ is the removal rate constant at $20{ }^{\circ} \mathrm{C}(1 /$ day) and $\theta$ is the temperature correction factor), $t$ is the HRT (day).

Table 2. Experimental parameters and their measurement methods

\begin{tabular}{ccc}
\hline Item & $\begin{array}{c}\text { Analytical } \\
\text { technique }\end{array}$ & $\begin{array}{c}\text { Standard method } \\
\text { number or } \\
\text { apparatus }\end{array}$ \\
\hline $\mathrm{TKN}$ & Kjeldahl Method & $\mathrm{SM}-4500 \mathrm{~A} \mathrm{~B}$ \\
\hline $\mathrm{NH}_{4}-\mathrm{N}$ & $\begin{array}{c}\text { Distillation, } \\
\text { titrimetric method }\end{array}$ & $\mathrm{SM}-4500 \mathrm{~B}-\mathrm{C}$ \\
\hline $\mathrm{NO}_{3}-\mathrm{N}$ & $\begin{array}{c}\text { lon } \\
\text { Chromatography }\end{array}$ & $\mathrm{SM}-4110 \mathrm{~B}$ \\
\hline $\mathrm{BOD}$ & $\begin{array}{c}\text { Respirometric } \\
\text { (manometric) } \\
\text { method }\end{array}$ & $\begin{array}{c}\text { By using WTW } \\
\text { OxiTop IS 6 }\end{array}$ \\
\hline
\end{tabular}

Note: Concentrations of $N_{\text {org. }}$ were calculated as the difference between $\mathrm{TKN}$ and $\mathrm{NH}_{4}^{-}-\mathrm{N}$ concentrations, and because all concentrations of nitrite-nitrogen $\left(\mathrm{NO}_{2}^{-}-\mathrm{N}\right)$ were measured below $0.8 \mathrm{mg} / \mathrm{L}$, they were not taken into account for $T N$

\subsection{Statistical analysis}

Statistical analysis was carried out applying SPSS 24.0 (IBM SPSS Statistics Software, 2016) to assess the effect of nitrogen loading rates and different seasons on treatment efficiencies of the systems and to check whether or not the difference between the inlet and outlet concentrations was statistically significant. Pearson's correlation was used to evaluate relationships between variables based on $p$-values at 0.05 level (twotailed).

\section{Results and discussion}

\subsection{Changes in influent and effluent concentrations and removal efficiencies}

In the majority of the previous studies on the CW and OF systems, it was reported that the monthly and annual trends in the influent and effluent TKN $\left(\mathrm{NH}_{4}^{+}-\mathrm{N}\right.$ and $\mathrm{N}_{\text {org. }}$.) concentrations were often sinusoidal (Crites et al., 2006; Kadlec and Wallace, 2009).

In this study, the seasonal influent and effluent concentrations of TKN and TN varied in a similar manner to the sinusoidal, while decreasing $\mathrm{NO}_{3}{ }^{-} \mathrm{N}$ and increasing $\mathrm{TN}$ in spring towards the end of the operation period (Figure 3). The pearson correlation coefficients (0.84-0.99) and $p$-values ( $p=0.000001-0.001<0.05$ ) indicated that the relationships between influent and effluent concentrations were significant and the influent concentrations had a positive impact on the effluent concentrations. Average influent and effluent concentrations $(\mathrm{mg} / \mathrm{L})$ of the SB system in the second stage of the hybrid system were 29 and 25 for $\mathrm{NH}_{4}{ }^{+}-\mathrm{N}$, 15 and 11 for $\mathrm{N}_{\text {org., }} 0.9$ and 1.5 for $\mathrm{NO}_{3}-\mathrm{N}$, and 44 and 38 for TN. The $\mathrm{NH}_{4}^{+}-\mathrm{N}$ and $\mathrm{TN}$ concentrations in the effluent of the second stage SB system did not change significantly as the removal efficiencies tended to decrease towards the end of the operation period.
This proved that the anaerobic conditions in the bottom sludge were not yet dominant.

Average influent and effluent concentrations $(\mathrm{mg} / \mathrm{L}$ ) of the FWS-CW system, which was the third stage of the hybrid system, were 25 and 16 for $\mathrm{NH}_{4}{ }^{+}-\mathrm{N}, 11$ and 6 for $\mathrm{N}_{\text {org., }} 1.5$ and 1.8 for $\mathrm{NO}_{3}-\mathrm{N}$, and 38 and 25 for $\mathrm{TN}$. Removal efficiencies of the FWS-CW system except for $\mathrm{NO}_{3}{ }^{-}-\mathrm{N}$, after an initial decline, increased as effluent concentrations decreased, peaking at over $40 \%$ for $\mathrm{NH}_{4}{ }^{+}-\mathrm{N}$ and $\mathrm{TN}$, and $35 \%$ for $\mathrm{N}_{\text {org., }}$ in spring towards the end of the operation period.

Average influent and effluent concentrations ( $\mathrm{mg} / \mathrm{L}$ ) of the OF system, which was the last stage of the hybrid system, were 16 and 12 for $\mathrm{NH}_{4}^{+}-\mathrm{N}, 6$ and 5 for $\mathrm{N}_{\text {org. }} 1.8$ and 2.3 for $\mathrm{NO}_{3}{ }^{-} \mathrm{N}$, and 25 and 19 for $\mathrm{TN} . \mathrm{NO}_{3}-\mathrm{N}$ removal efficiencies in the OF system showed a similar trend as those of the FWS-CW system. While $\mathrm{N}_{\text {org. }}$ removal efficiencies of the OF system decreased towards the end of the operation period, $\mathrm{NO}_{3}{ }^{-}-\mathrm{N}$ removal efficiencies increased slightly towards the end of the operation period. $\mathrm{NH}_{4}{ }^{+}-\mathrm{N}$ removal did not change much during the operation period. $\mathrm{NH}_{4}{ }^{+}-\mathrm{N}$ in the OF system could be possibly removed through the ion exchange-plant uptakenitrification mechanisms during the operating period. Although the FWS and OF system had sufficient carbon to support denitrification, $\mathrm{NO}_{3}^{-}-\mathrm{N}$ could not be removed. This may possibly be due to the sufficient oxygen supply through the plants (Phragmites australis and Italian ryegrass) and the atmospheric diffusion into the systems.

The FWS-CW system apparently achieved a better $\mathrm{NH}_{4}{ }^{+}-\mathrm{N}$, $\mathrm{N}_{\text {org., }}$ and TN removal efficiency, probably due to emergent plants, the higher treatment volume, and hydraulic residence time (HRT). In addition, a substantial amount of nitrogen can be immobilized in sediment by microbial biomass (Behrendt, 1996). For example, Qualls (1984) estimated that nitrogen immobilization by microbial biomass in sediment in a swamp stream draining agricultural lands could account for as much as $25 \%$ of the inorganic nitrogen inflow into the system during high flow conditions.

TN removal of the FWS-CW system ranged from approximately $6 \%$ to $72 \%$ and was quite close to the values recorded in other studies (Juang and Chen, 2007; Wu et al., 2009; Yuan et al., 2012; Tang et al., 2013). TN removal in the OF system ranges from $12 \%$ to $48 \%$ and is lower (20-90\%) than those reported in the literature, possibly due to much higher $\mathrm{TN}$ loading rates (0.1-2.7 g/m²/d) (Crites et al., 2006).

In previous studies, the OF systems were operated in the batch mode and at lower $\mathrm{NH}_{4}{ }^{+}-\mathrm{N}$ and TN loading rates than $1.0 \mathrm{~g} / \mathrm{m}^{2} / \mathrm{d}$. In this study, although the OF system was operated at the continuous-flow mode and in higher loading rates, its $\mathrm{NH}_{4}{ }^{+}-\mathrm{N}$ and $\mathrm{TN}$ removal efficiency might be regarded as satisfactory (Crites et al., 2000).

$\mathrm{NH}_{4}{ }^{+}-\mathrm{N}$ removal efficiency in the FWS-CW system seems quite close to the values recorded in other studies (Juang and Chen, 2007; Kadlec and Wallace, 2009; Wu et al., 2009; Yuan et al., 2012; Tang et al., 2013) on 
nitrogen removal, despite much higher loading rates and BOD/TKN ratios.

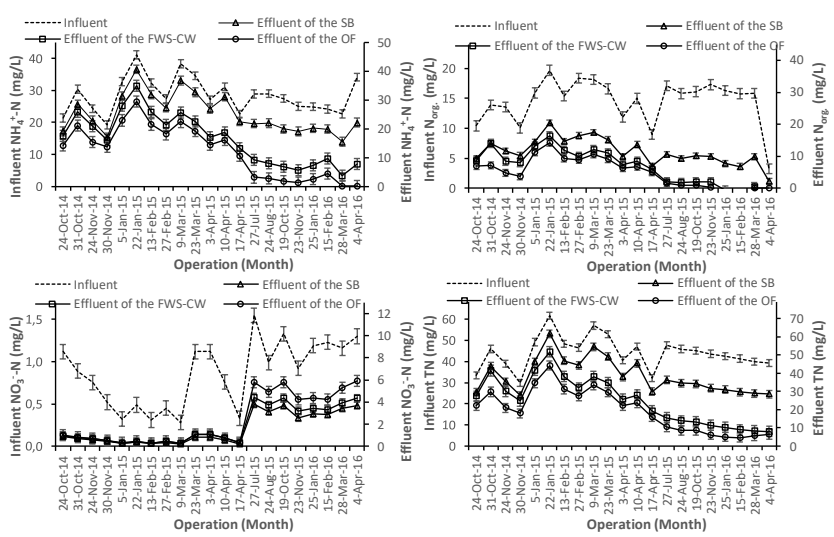

Figure 3. Changes in influent and effluent $\mathrm{NH}_{4}{ }^{+}-\mathrm{N}, \mathrm{N}_{\text {org., }} \mathrm{NO}_{3}{ }^{-}-\mathrm{N}$ and TN concentrations

In general, the hybrid system dropped $\mathrm{NH}_{4}{ }^{+}-\mathrm{N}$ from $29 \mathrm{mg} / \mathrm{L}$ up to $12 \mathrm{mg} / \mathrm{L}$ with an average removal efficiency of $57 \%, \mathrm{~N}_{\text {org. }}$ from $15 \mathrm{mg} / \mathrm{L}$ up to $5 \mathrm{mg} / \mathrm{L}$ with an average removal efficiency of $67 \%$, and $\mathrm{TN}$ from $44 \mathrm{mg} / \mathrm{L}$ up to $19 \mathrm{mg} / \mathrm{L}$ with an average removal efficiency of $57 \%$ (Figure 4).

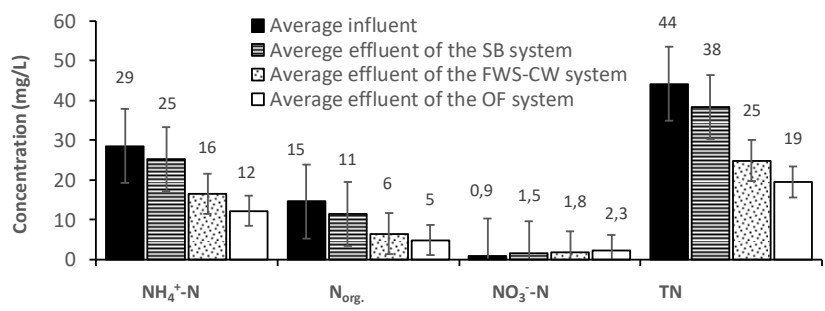

Figure 4. Comparison of performances of the SB, the FWS-CW, and the OF systems under operation conditions
In order to assess the effects of the seasons on nitrogen removal efficiencies of the FWS-CW and OF system, the average values of the concentrations and removal efficiencies obtained at the air temperatures of the average $6^{\circ} \mathrm{C}$ and $22^{\circ} \mathrm{C}$ were compared. Results were summarized in Table 3. The highest removals for all the pollutants were achieved in the warmer seasons, probably due to the moderate temperature needed for the active actions of microorganisms and the growth period of the plants (Verhoeven and Meuleman, 1999; Kuschk et al., 2003). The Pearson correlation coefficients (0.85-0.92 for the FWS-CW, 0.60-0.77 for the OF) and p-values clearly revealed that water temperature had significant $((p=0.000 . .<0.05$ for the FWS-CW, $p=0.02-0.04<0.05$ for the OF)) and positive effects on the average $\mathrm{NH}_{4}{ }^{+}-\mathrm{N}$, Norg., and TN removals of the FWS-CW and the OF system during operating period.

Both the FWS-CW and the OF system yielded lower effluent $\mathrm{NH}_{4}{ }^{+}-\mathrm{N}, \mathrm{N}_{\text {org., }}$ and TN concentrations in warmer seasons and thus increasing removal efficiencies. These results are consistent with much of the literature (Crites et al., 2006; Vymazal, 2008; Kadlec and Wallace, 2009). On the other hand, Jenssen and Mæhlum (2003) reported that there was no significant difference in TN removal efficiency between colder $\left(<4^{\circ} \mathrm{C}\right)$ and warmer (> $11^{\circ} \mathrm{C}$ ) periods in the CWs in Norway. Removal efficiencies of the FWS-CW system were lower in colder seasons, probably because the decreasing bacterial activities and ice covered its open water, and thus the transfer of oxygen from the atmosphere was reduced, decreasing oxygen and temperature dependent $\mathrm{NH}_{4}{ }^{+}-\mathrm{N}$ oxidation (Kadlec and Wallace, 2009).

\subsection{Seasonal variations}

Table 3. Comparison of influent and effluent concentrations and their percent removals in the FWS-CW and the OF system as a function of colder and warmer seasons

\begin{tabular}{|c|c|c|c|c|c|}
\hline Systems & Parameter & Seasons & $\begin{array}{c}\text { Influent } \\
\text { (mg/L) }\end{array}$ & $\begin{array}{c}\text { Effluent } \\
\text { (mg/L) }\end{array}$ & $\begin{array}{c}\text { Removals } \\
\text { (\%) }\end{array}$ \\
\hline \multirow[t]{6}{*}{ FWS-CW } & $\mathrm{NH}_{4}{ }^{+}-\mathrm{N}$ & Colder seasons ${ }^{1}$ & 28.6 & 21.2 & 26 \\
\hline & & Warmer seasons ${ }^{2}$ & 21.9 & 8.6 & 61 \\
\hline & Norg. & Colder seasons ${ }^{1}$ & 13.4 & 7.7 & 42 \\
\hline & & Warmer seasons ${ }^{2}$ & 10.0 & 1.9 & 81 \\
\hline & TN & Colder seasons ${ }^{1}$ & 43.3 & 30.4 & 30 \\
\hline & & Warmer seasons ${ }^{2}$ & 35.4 & 14.7 & 59 \\
\hline \multirow[t]{6}{*}{ OF } & $\mathrm{NH}_{4}^{+}-\mathrm{N}$ & Colder seasons ${ }^{1}$ & 21.2 & 16.5 & 22 \\
\hline & & Warmer seasons ${ }^{2}$ & 8.6 & 3.0 & 65 \\
\hline & Norg. & 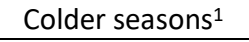 & 7.7 & 6.3 & 19 \\
\hline & & Warmer seasons ${ }^{2}$ & 1.9 & 1.2 & 39 \\
\hline & TN & Colde seasons ${ }^{1}$ & 30.4 & 24.5 & 19 \\
\hline & & Warmer seasons ${ }^{2}$ & 14.7 & 9.6 & 35 \\
\hline
\end{tabular}

"1" and " 2 " imply measured values at water temperatures of average 6 and $22^{\circ} \mathrm{C}$, respectively

Compared to colder seasons, while the nitrogen removals in the OF system were higher $26 \%$ on average, removals in the FWS-CW system were higher approximately $45 \%$ for $\mathrm{NH}_{4}{ }^{+}-\mathrm{N}, 39 \%$ for $\mathrm{N}_{\text {org. }}$, and $29 \%$ for TN. Probable causes for the low nitrate removal of the FWS-CW and OF system during the winter season may be due to the decreasing plant metabolism and the lower biomass (HowardWilliams et al., 1982; Birgand, 2007; Vymazal, 2010). 


\subsection{Loading rate influence on removal rate}

Figure 5 illustrates the relationships between nitrogen removal rates $\left(\mathrm{g} / \mathrm{m}^{2} / \mathrm{d}\right)$ and their loading rates $\left(\mathrm{g} / \mathrm{m}^{2} / \mathrm{d}\right)$. Over the range of loading rates studied, all exhibited a strong exponential relationship $\left(R^{2}>0.74\right)$.
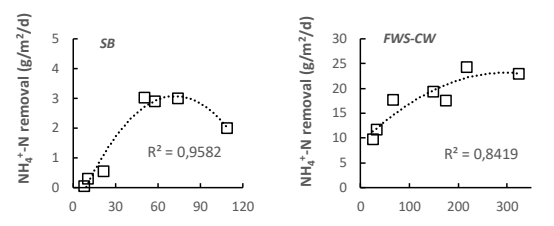

$\mathrm{NH}_{4}{ }^{+}-\mathrm{N}$ loading $\left(\mathrm{g} / \mathrm{m}^{2} / \mathrm{d}\right)$

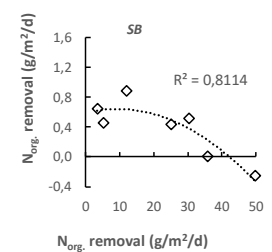

$\mathrm{NH}_{4}{ }^{+}-\mathrm{N}$ loading $\left(\mathrm{g} / \mathrm{m}^{2} / \mathrm{d}\right)$

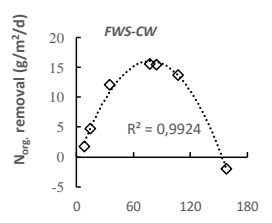

$\begin{array}{lrr}0 & 60 & 120 \\ N_{\text {orge }} \text { removal }\left(g / \mathrm{m}^{2} / \mathrm{d}\right)\end{array}$
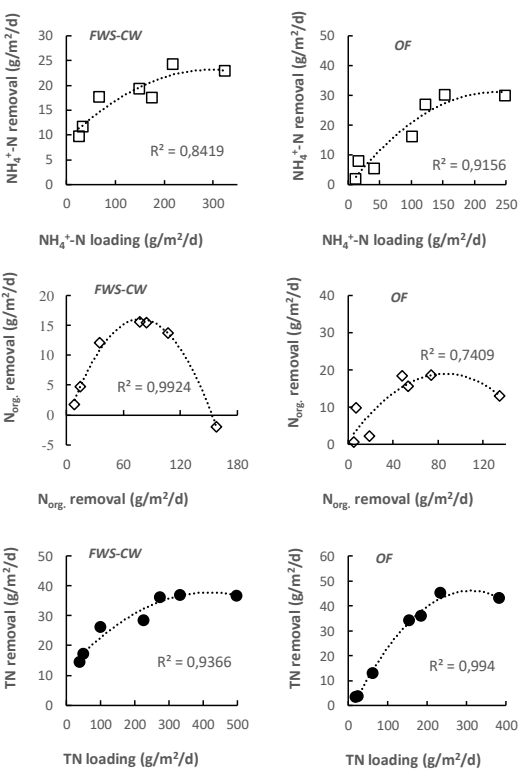
$\mathrm{NH}_{4}{ }^{+}-\mathrm{N}$ loading $\left(\mathrm{g} / \mathrm{m}^{2} / \mathrm{d}\right)$

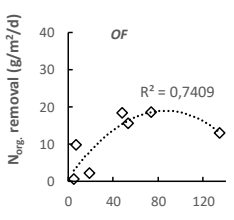

$N_{\text {org. }}$ removal $\left(\mathrm{g} / \mathrm{m}^{2} / \mathrm{d}\right)$

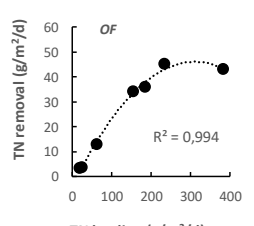

TN loading $\left(g / \mathrm{m}^{2} / \mathrm{d}\right)$

Figure 5. $\mathrm{NH}_{4}{ }^{+}-\mathrm{N}, \mathrm{N}_{\text {org. }}$ and TN removal $\left(\mathrm{g} / \mathrm{m}^{2} / \mathrm{d}\right)$ as a function of their loading rates $\left(\mathrm{g} / \mathrm{m}^{2} / \mathrm{d}\right)$

There was a highly significant difference between loading rates and their removal rates of nitrogen species except for $N_{\text {org. }}(p<0.05)$. In general, there was an overall upward trend of removal rates to a certain extent in response to loading rates. A hump-shaped curve, which was similar to those reported by other researchers (Mulholland et al., 2004; Crites et al., 2006; Kadlec and Wallace, 2009; Gajewska et al., 2015; Latrach et al., 2018), was found for the removal rates $\left(\mathrm{g} / \mathrm{m}^{2} / \mathrm{d}\right)$ versus the loading rates $\left(\mathrm{g} / \mathrm{m}^{2} / \mathrm{d}\right) . \mathrm{NH}_{4}{ }^{+}-\mathrm{N}$ and $\mathrm{TN}$ removal rates of the systems tended to increase with loading rates up to reach a stable level. Apparently, removal rates and its mass loading rate had a significant correlation (all $R^{2}>0.84, p<0.05$ ) in the systems. Optimum loading rates were approximately $60 \mathrm{~g}$ $\mathrm{NH}_{4}{ }^{+}-\mathrm{N} / \mathrm{m}^{2} / \mathrm{d}$ and $100 \mathrm{~g} \mathrm{TN} / \mathrm{m}^{2} / \mathrm{d}$ for the SB, $200 \mathrm{~g} \mathrm{NH}_{4}{ }^{+}-\mathrm{N}$ $/ \mathrm{m}^{2} / \mathrm{d}$ and $300 \mathrm{~g} \mathrm{TN} / \mathrm{m}^{2} / \mathrm{d}$ for the FWS-CW, and $150 \mathrm{~g}$ $\mathrm{NH}_{4}{ }^{+}-\mathrm{N} / \mathrm{m}^{2} / \mathrm{d}$ and $220 \mathrm{~g} \mathrm{TN} / \mathrm{m}^{2} / \mathrm{d}$ for the OF system. In spite of the higher optimum loadings, optimum removals in the FWS-CW system were higher than the SB system, and approximately at the same levels as the OF system.

Average loading and removal rates $\left(\mathrm{g} / \mathrm{m}^{2} / \mathrm{d}\right)$ and removal rate constants $\left(k_{20}\right)$ of each system were in summarized in Table 4. As shown in Table 4, in spite of the higher loading rates, $\mathrm{NH}_{4}{ }^{+}-\mathrm{N}$ and $\mathrm{TN}$ removal rates and removal rate constants $\left(k_{20}\right)$ of the FWS-CW system were higher than other ones, probably due to the higher treatment volume and HRTs (average 11 days). $\mathrm{NH}_{4}{ }^{+}-\mathrm{N}$ removal rate constants in the FWS-CW and the OF systems were reported over a wide range between $0.88 /$ day and 2.28/day (Jing et al., 2002; Crites et al., 2006; Kadlec and

Wallace, 2009). In this study, $\mathrm{k}_{20}$ values for $\mathrm{NH}_{4}{ }^{+}-\mathrm{N}$ in the FWS-CW and the OF system were considerably lower than the values in the literature, probably due to much higher loading rates. Nitrogen removal rates of the SB system were considerably lower than other ones, due to only physical sedimentation and nitrate removal in anaerobic conditions.

Table 4. Average loading and removal rates $\left(\mathrm{g} / \mathrm{m}^{2} / \mathrm{d}\right)$ and removal rate constants $\left(k_{20}\right)$ in the systems

\begin{tabular}{lllll}
\hline Parameters & Items & SB & FWS & OF \\
\hline & $\begin{array}{l}\text { Average load rate } \\
\left(\mathrm{g} / \mathrm{m}^{2} / \mathrm{d}\right)\end{array}$ & 48 & 141 & 99 \\
\hline $\mathrm{NH}_{4}{ }^{+}-\mathrm{N}$ & $\begin{array}{l}\text { Average removal } \\
\text { rate }\left(\mathrm{g} / \mathrm{m}^{2} / \mathrm{d}\right)\end{array}$ & 2 & 18 & 17 \\
\hline & $\mathrm{k}_{20}(1 /$ day) & & 0.24 & 0.22 \\
\hline & $\begin{array}{l}\text { Average load rate } \\
\text { (g/m } / \mathrm{d})\end{array}$ & 23 & 70 & 49 \\
\hline $\mathrm{N}_{\text {org. }}$ & $\begin{array}{l}\text { Average removal } \\
\text { rate }\left(\mathrm{g} / \mathrm{m}^{2} / \mathrm{d}\right)\end{array}$ & 0.4 & 9 & 11 \\
\hline & $\begin{array}{l}\mathrm{k}_{20}(1 / \text { day }) \\
\text { Average load rate } \\
\left(\mathrm{g} / \mathrm{m}^{2} / \mathrm{d}\right)\end{array}$ & 73 & 217 & 152 \\
\hline $\mathrm{TN}$ & $\begin{array}{l}\text { Average removal } \\
\text { rate }\left(\mathrm{g} / \mathrm{m}^{2} / \mathrm{d}\right)\end{array}$ & 3 & 28 & 25 \\
\hline & $\mathrm{k}_{20}(1 /$ day $)$ & & 0.24 & 0.21 \\
\hline
\end{tabular}

3.4. Removal rates and change of nitrification rate as a function of the BOD/TKN ratio

The relationships between the BOD/TKN ratio and nitrification rate were shown in Figure 6. Studies carried out by Miksch and Sikora (2010) indicated that nitrogen removal efficiency was over $90 \%$ when the BOD/TKN was over 4 for conventional wastewater treatment processes (Gajewska et al., 2015). Recommended BOD/TKN ratio for biological treatment systems was in the range 2-5 (Reed et al., 1995; Crites et al., 2006; Kadlec and Wallace, 2009; Gajewska et al., 2015).
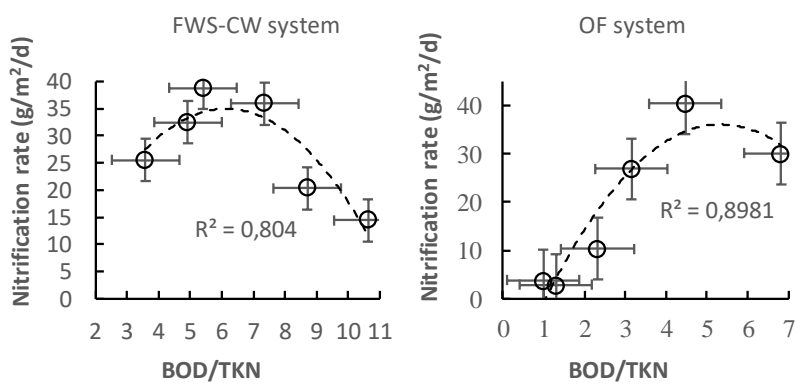

Figure 6. Change of nitrification rates $\left(\mathrm{g} / \mathrm{m}^{2} / \mathrm{d}\right)$ as a function of BOD/TKN ratios

In this study, the nitrification rate increased with increasing the BOD/TKN ratio, up to 5 . This implies that population of nitrifying bacteria may be high at the lower BOD/TKN ratios than 5 , and thus the heterotrophic BOD oxidation cannot have much effect on the nitrification (Tchobanoglous et al., 2003). At the higher BOD/TKN ratios than 5 , nitrification rate showed a decreasing trend. This may be probably because of the lower fraction of 
nitrifying organisms and heterotrophic competition in the oxidation of BOD. The carbon consumption activity of heterotrophs may cause them to dominate the overall bacterial population, but with increasing nitrification bacteria at a slow rate from $3 \%$ to $35 \%$ and with decreasing the BOD/TKN ratio from 9 to 0.5 (Tchobanoglous et al., 2003). In addition, theoretical dissolved oxygen demands for full nitrification of TKN varied between 0.0 to $7.1 \mathrm{~g} / \mathrm{m}^{2} / \mathrm{d}$ (Kadlec and Wallace, 2009). Dissolved oxygen the in the effluent of the FWS-CW system ranged between 0.2 to $8.4 \mathrm{~g} / \mathrm{m}^{2} / \mathrm{d}$ (average $1.7 \mathrm{~g} / \mathrm{m}^{2} / \mathrm{d}$ ) and was found sufficient for full nitrification.

\subsection{HRT influence on removal efficiency}

To examine nitrogen removal efficiency of the hybrid system at different HRTs and define an optimal HRT, all its stages were operated at five different HRTs. The average effluent nitrogen concentrations of the systems were shown in Figure 7 as a function of the HRT.

As shown in Figure 7, the average effluent nitrogen concentrations $(\mathrm{mg} / \mathrm{L})$ exhibited a similar change in all stages, depending on the HRTs (day). The average effluent nitrogen concentrations first displayed an exponential increase and decreased after approximately 4.0 days. Data from Figure 7 indicates that the planted systems produces the lowest effluent concentrations at the highest HRTs after approximately 6.0 days. During HRT periods after 20 days for the FWS-CW system and 6.0 days for the OF system. While the OF system produced an average TN effluent of $24 \mathrm{mg} / \mathrm{L}$ during HRT periods after 6.0 days, the FWS-CW system produced an average TN effluent of $24 \mathrm{mg} / \mathrm{L}$ during HRT periods after 20 days. These results indicated that the planted systems might provide higher nitrogen removal efficiencies during HRT periods after 6.0 days. The statistical evaluation showed that the HRT had a significant effect $(p<0.05)$ on $\mathrm{NH}_{4}{ }^{+}-\mathrm{N}$, Norg., and TN removal efficiencies. Correspondingly, it is notable that increasing HRTs markedly improved nitrogen removal efficiencies. Most studies of the FWS-CW and the OF systems have shown that long HRTs or lower hydraulic loading rates (HLRs) typically result in better removal efficiencies (Behrendt, 1996; Behrendt and Opitz, 2000; Crites et al., 2006; Birgand et al., 2007; Kadlec and Wallace, 2009).

\subsection{Filtration influence on removal efficiency}

Table 5 shows average influent and effluent $\mathrm{NH}_{4}{ }^{+}-\mathrm{N}, \mathrm{N}_{\text {org }}$, and TN concentrations $(\mathrm{mg} / \mathrm{L}$ ) of the FWS-CW and OF system and their percent removals during the operation periods after and before the use of the filter material in the FWS-CW. The use of the filter material in the FWS-CW system may increase the number of bacteria oxidizing nitrogenous compounds, and thus nitrogen removal efficiency of the system may improve (Vymazal, 2008; Kadlec and Wallace, 2009). In this study, during loadings after the use of the filter material in the FWS-CW system, average effluent $\mathrm{NH}_{4}{ }^{+}-\mathrm{N}, \mathrm{N}$ org., and TN concentrations of the FWS-CW and the OF system tended to decrease.

The analysis of variance showed that the use of the filter material significantly affected percent $\mathrm{NH}_{4}{ }^{+}-\mathrm{N}$ and $\mathrm{TN}$ removals in both the FWS-CW and the OF system ( $p<0.05$ ). Percent $\mathrm{NH}_{4}{ }^{+}-\mathrm{N}$ and $\mathrm{TN}$ removals in the FWS-CW and the OF system after the use of the filter material were calculated to be about $8 \%$ and $3 \%$ higher than non-filtration, respectively. These results demonstrated that the use of the filter materials such as gravel in the FWS-CW systems might enhance its nitrogen removal efficiency.
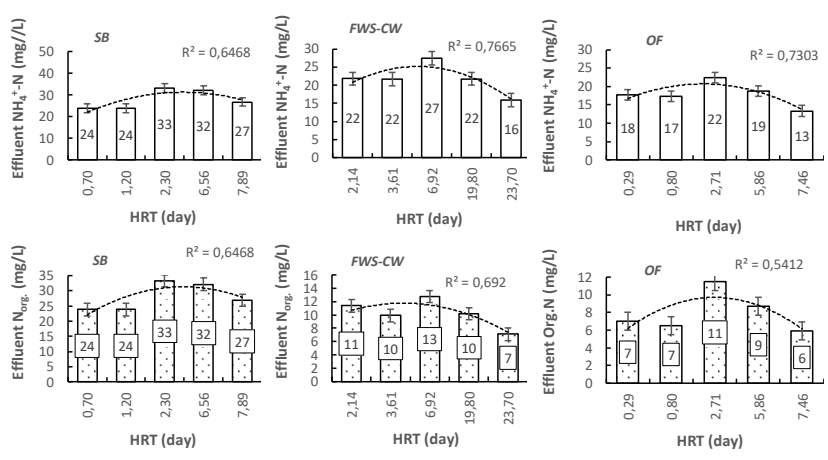
HRT (day)
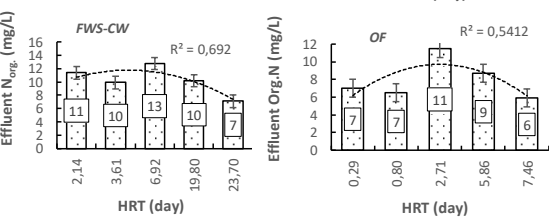

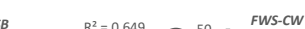
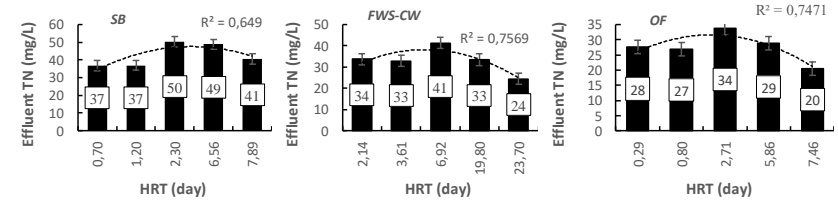

Figure 7. Relationship between HRT and effluent concentrations for $\mathrm{NH}_{4}{ }^{+}-\mathrm{N}, \mathrm{N}_{\text {org. }}$ and $\mathrm{TN}$

\section{Conclusion}

In this research, a hybrid NWT system was designed to achieve nitrogen removal from an over-polluted creek, and the effect of hydraulic and nitrogen loading rate, temperature, seasonal variation, BOD/TKN ratio, HRT, and the use of the filter material on nitrogen removal was studied. TN removal was very low in the second stage (SB) with the average removal of $14 \%$. Despite the higher nitrogen loading rates, the FWS-CW system, which was the third stage of the hybrid system, achieved the higher TN removal efficiency (34\%) due to the emergent plants, the higher treatment volume, and HRT (average 11 days). The OF system, which was operated as a final stage with the aim of the further nitrogen removal at the average HRT of 3.3 days, achieved TN removal efficiency of $24 \%$. Removal efficiencies in the FWS-CW and the OF system were affected by the seasonal changes. The average removals of the FWS-CW and the OF system were the higher in the warmer seasons that the plants might grow best. In accordance with previous studies, experimental results revealed that the HRT was an important factor affecting the performance of the FWS-CW and the OF system. There was typically an exponential decrease in removal rates $\left(\mathrm{g} / \mathrm{m}^{2} / \mathrm{d}\right)$ with increasing nitrogen loading rates $\left(\mathrm{g} / \mathrm{m}^{2} / \mathrm{d}\right)$. Results indicated that removal rates first increased, and then reached a stable or optimum level with increasing loading rates. Nitrification rate in the FWS-CW and the OF system increased with increasing $\mathrm{BOD} / \mathrm{TKN}$ ratio up to 5 , and nitrification rate showed a 
decreasing trend at the higher BOD/TKN ratios than 5 . The use of filter material were the higher compared to before the use of the filter material. This result indicated that use of the filter material in the FWS-CW system positively affected removal efficiency of the hybrid system. Overall, the results obtained from this study showed that the hybrid NWT system might be used as a low-cost wastewater treatment alternative to improve the water quality of over-polluted streams in the similar areas.

Table 5. Influent and effluent $\mathrm{NH}_{4}{ }^{+}-\mathrm{N}, \mathrm{N}_{\text {org., }}$ and TN concentrations $(\mathrm{mg} / \mathrm{L})$ and percent removals of the FWS-CW and the OF system after and before the use of filter material in the FWS-CW

\begin{tabular}{|c|c|c|c|c|c|}
\hline \multirow[b]{2}{*}{ Systems } & \multirow[b]{2}{*}{ Parameter } & \multirow[b]{2}{*}{ Operation mode } & \multicolumn{3}{|c|}{ FWS-CW system } \\
\hline & & & $\begin{array}{l}\text { Influent } \\
\text { (mg/L) }\end{array}$ & $\begin{array}{l}\text { Effluent } \\
\text { (mg/L) }\end{array}$ & $\begin{array}{c}\text { Removals } \\
\text { (\%) }\end{array}$ \\
\hline \multirow{6}{*}{ FWS-CW } & \multirow[b]{2}{*}{$\mathrm{NH}_{4}^{+}-\mathrm{N}$} & Before filter material use & 34.77 & 24.11 & 31 \\
\hline & & After filter material use & 26.85 & 16.33 & 39 \\
\hline & \multirow{2}{*}{$\mathrm{N}_{\text {org }}$} & Before filter material use & 16.28 & 11.55 & 29 \\
\hline & & After filter material use & 10.17 & 7.21 & 29 \\
\hline & \multirow{2}{*}{$\mathrm{TN}$} & Before filter material use & 47.20 & 32.90 & 30 \\
\hline & & After filter material use & 37.66 & 23.66 & 37 \\
\hline \multirow{6}{*}{ OF } & \multirow{2}{*}{$\mathrm{NH}_{4}^{+}-\mathrm{N}$} & Before filter material use & 24.11 & 20.88 & 13 \\
\hline & & After filter material use & 16.33 & 13.75 & 16 \\
\hline & \multirow[b]{2}{*}{$\mathrm{N}_{\text {org }}$} & Before filter material use & 11.55 & 9.87 & 15 \\
\hline & & After filter material use & 7.21 & 6.05 & 16 \\
\hline & \multirow{2}{*}{$\mathrm{TN}$} & Before filter material use & 36.45 & 31.51 & 14 \\
\hline & & After filter material use & 23.37 & 20.58 & 16 \\
\hline
\end{tabular}

\section{Acknowledgements}

This research was supported by the Scientific and Technical Research Council of Turkey (TUBITAK), through the Project N: 113Y589. The author wishes to thank the TUBITAK for financial support.

\section{References}

Aguiar V.M.C., Neto J.A.B. and Rangel C.M. (2011), Eutrophication and Hypoxia in Four Streams Discharging in Guanabara Bay, RJ, Brazil, a Case Study, Marine Pollution Bulletin, 62, 1915-1919.

APHA, Standard Methods for the Examination of Water and Wastewater, 20th edition. American Public Health Association, Washington, D.C., 1998.

Behrendt H. and Opitz D. (2000), Retention of nutrients in river systems: Dependence on specific runoff and hydraulic load, Hydrobiologia, 410, 111-122.

Behrendt H. (1996), Inventories of point and diffuse sources and estimated nutrient loads-A comparison for different river basins in central Europe, Water Science and Technology, 33, 99-107.

Birgand F., Skaggs R.W., Chescheir G.M. and Gilliam J.W. (2007), Nitrogen removal in streams of agricultural catchments-a literature review, Critical Reviews in Environmental Science and Technology, 37: 381-487.

Crites R.W., Middlebrooks J. and Reed S.C. (2006), Natural Wastewater Treatment Systems, Taylor \& Francis Group, CRC Press, USA.
Crites R.W., Reed S.C. and Bastian R.K. (2000), Land Treatment Systems for Municipal and Industrial Wastes, McGraw-Hill Companies, USA.

Crites R.W. and Tchobanoglous G. (1998), Small and Decentralized Wastewater Management Systems, McGrawHill, New York, NY.

Cui N., Wu J., Xiang D., Cheng S. and Zhou Q. (2013), A field study on seed bank and its potential applications in vegetation restoration of a polluted urban river in China, Ecological Engineering, 60, 37-44.

Gajewska M., Jóźwiakowski K., Ghrabi A. and Masi F. (2015), Impact of influent wastewater quality on nitrogen removal rates in multistage treatment wetlands, Environmental Science and Pollution Research, 22(17), 12840-12848.

Howard-Williams C., Davies J. and Pickmere S. (1982), The dynamics of growth, the effects of changing area and nitrate uptake by watercress Nasturtium officinale R. Br. in a New Zealand stream, Journal of Applied Ecology, 19, 589601.

Hunt P.G., Stone K.C., Humenik F.J., Matheny T.A. and Johnson M.H. (1999), In-stream wetland mitigation of nitrogen contamination in a USA coastal plain stream, Journal of Environmental Quality, 28(1), 249-256.

IBM SPSS Statistics Software, International Business Machines Corporation, version 24, 2016.

Jenssen P.D. and Mæhlum T. (2003), Treatment performance of multistage wastewater constructed wetlands in Norway, In Ü. Mander, C. Vohla and A. Poom (Eds.), Proceedings of International Conference on Constructed and Riverine Wetlands for Optimal Control of Wastewater at Catchment 
Scale (pp. 11-16), University of Tartu, Institute of Geography, Tartu, Estonia.

Jing S.R., Lin Y.F., Lee D.Y. and Wang T.W. (2002), Performance of constructed wetlands planted with various macrophytes and using high hydraulic loading, Journal of Environmental Quality, 31(2), 690-696.

Juang D.F. and Chen P.C. (2007), Treatment of polluted river water by a new constructed wetland, International Journal of Environmental Science and Technology, 4, 481-488.

Kadlec R.H. and Hey D.L. (1994), Constructed wetlands for river water quality improvement, Water Science and Technology, 29(4), 159-168.

Kadlec R.H. and Knight R.L. (1996), Treatment Wetlands, CRC Press LLC, Lewis Publishers, Boca Raton, New York, USA.

Kadlec R.H. and Wallace S.D. (2009), Treatment Wetlands, Second Ed., CRC Press, Boca Raton, FL USA.

Kim B., Gautier M., Prost-Boucle S., Molle P., Michel P. and Gourdon R. (2014), Performance evaluation of partially saturated vertical-flow constructed wetland with trickling filter and chemical precipitation for domestic and winery wastewaters treatment, Ecological Engineering, 71, 41-47.

Kuschk P., Wiessner A., Kappelmeyer U., Weibbrodt E., Kastner M. and Stottmeister U. (2003), Annual cycle of nitrogen removal by a pilotscale subsurface horizontal flow in a constructed wetland under moderate climate, Water Research, 37(17), 4236-4242.

Lai D.Y.F. (2014), Phosphorus fractions and fluxes in the soils of a free surface flow constructed wetland in Hong Kong, Ecological Engineering, 73, 73-79.

Latrach L., Ouazzani N., Hejjaj A., Mahi M., Masunaga T. and Mandi L. (2008), Two-stage vertical flow multi-soil-layering (MSL) technology for efficient removal of coliforms and human pathogens from domestic wastewater inrural areas under arid climate, The International Journal of Hygiene and Environmental Health, 221, 64-68.

Li F., Lu L., Zheng X. and Zhang X. (2014), Three-stage horizontal subsurface flow constructed wetlands for organics and nitrogen removal: effect of aeration, Ecological Engineering, 68, 90-96.

Li Y., Cao W., Su C. and Hong H. (2011), Nutrient Sources and Composition of Recent Algal Blooms and Eutrophication in the Northern Jiulong River, Southeast China, Marine Pollution Bulletin, 63, 249-254.

Lin J.L., Tu Y.T., Chiang P.C., Chen S.H. and Kao C.M. (2015), Using aerated gravel-packed contact bed and constructed wetland system forpolluted river water purification: A case study in Taiwan, Journal of Hydrology, 525, 400-408.

Mayer P.M., Striz E.A., Shedlock R., Doheny E.J. and Groffman P.M. (2004), The Effects of Ecosystem Restoration on Nitrogen Processing in an Urban Mid-Atlantic Piedmont Stream, U.S. Department of Agriculture, Agricultural Research Service, 536-541 pages, Washington, D.C.

Miksch K. and Sikora J. (2010), Biotechnologia ścieków, Wydawnictwo Naukowe PWN. Warszawa, Poland.

Morató J., Codony F., Sánchez O., Pérez L.M., García J. and Mas J. (2014), Key design factors affecting microbial community composition and pathogenic organism removal in horizontal subsurface flow constructed wetlands, The Science of the Total Environment, 481, 81-89.

Mulholland P.J., Valett H.M., Webster J.R., Thomas S.A., Cooper L.W., Hamilton S.K. and Peterson B.J. (2004), Stream denitrification and total nitrate uptake rates measured using a field $15 \mathrm{~N}$ tracer addition approach, Limnology and Oceanography, 49, 809-820.

Nakamura K., Tockner K. and Amano K. (2006), River and wetland restoration: lessons from Japan, Bioscience, 56, 419429.

Nishihiro J., Nishihiro M.A. and Washitani I. (2006), Assessing the potential for recovery of lakeshore vegetation: species richness of sediment propagule banks, Ecology Research, 21, 436-445.

Qualls R.G. (1984), The role of leaf litter nitrogen immobilization in the nitrogen budget of a swamp stream, Journal of Environmental Quality, 13, 640-644.

Reed S.C., Crites R.W. and Middlebrooks E.J. (1995), Natural Systems for Waste Management and Treatment, Second Edition, McGraw-Hill, New York, NY.

Royal Commission (Royal Commission on the Future of the Toronto Waterfront) (1992), Regeneration: Toronto's waterfront and the sustainable city: Final report. The Queen's Printer for Ontario, Toronto, Ontario, source pollution abatement, Transactions of the ASAE, 19(2), 171-175.

Søndergaard M. and Jeppesen E. (2007) Anthropogenic impacts on lake and stream ecosystems, and approaches to restoration, Journal of Applied Ecology, 44, 1089-1094.

Stone K.C., Hunt P.G., Novak J.M. and Johnson M.H. (2003), Instream wetland design for non-point ource pollution abatement, Applied Engineering in Agriculture, 19(2), 171175.

Tang W., Zhang W., Zhao Y., Wang Y. and Shan B. (2013), Nitrogen removal from polluted river water in a novel ditchwetland-pond system, Ecological Engineering, 60, 135-139.

Task Force to Bring Back the Don (1991), Bringing Back the Don. Report prepared, Toronto, Ontario.

Tchobanoglous G., Burton F.L. and Stensel H.D. (2003), Wastewater Engineering: Treatment and Reuse, Fourth ed., Metcalf \& Eddy Inc., McGraw-Hill, New York.

Tu Y.T., Chiang P.C., Yang J., Chen S.H. and Kao C.M. (2014), Application of a constructed wetland system for polluted stream remediation, Journal of Hydrology, 510, 70-80.

USEPA (United States Environmental Protection Agency), Manual: Constructed Wetlands Treatment of Municipal Wastewaters, EPA/625/R- 99/010, September 1999, National Risk Management Research Laboratory, Office of Research and Development, Cincinnati, $\mathrm{OH}, 1999$.

Verhoeven T.A.J. and Meuleman F.M.A. (1999), Wetlands for wastewater treatment: opportunities and limitations, Ecological Engineering, 12(1-2), 5-12.

Vymazal J. (2008), Wastewater Treatment, Plant Dynamics and Management in Constructed and Natural Wetlands, In J. Vymazal (Ed.), Springer, Czech Republic.

Vymazal J. (2010), Water and Nutrient Management in Natural and Constructed Wetlands, In J. Vymazal (Ed.), Springer, Czech Republic

Wu W.Z., Liu Y., Zhu Q., Wei C.J. and Wang J.L. (2009), Remediation of polluted river water by biological contact oxidation process using two types of carriers, International Journal of Environment and Pollution, 38, 223-234.

Yuan X.C., Qian X., Zhang R.B., Ye R. and Hu W. (2012), Performance and microbial community analysis of a novel bio-cord carrier during treatment of a polluted river, Bioresource Technology, 117, 33-39. 
Zhang J., Ni W., Luo Y., Stevenson R.J. and Qi J. (2011), Response of Freshwater Algae to Water Quality in Qinshan Lake Within Taihu Watershed, China, Physics and Chemistry of the Earth, 36, 360-365.

Zhou S. and Hosomi M. (2008), Nitrogen transformations and balance in a constructed wetland for nutrient-polluted river water treatment using forage rice in Japan, Ecological Engineering, 32, 147-155.

Zheng Y., Wang X., Xiong J. and Zhao Y. (2014), Hybrid constructed wetlands for highly polluted river water treatment and comparison of surface- and subsurface-flow cells, Journal of Environmental Science, 26, 749-756.

Züst B. and Schönborn A. (2003) Constructed wetlands for wastewater treatment in cold climates: Planted soil filter Schattweid-13 years' experience, In Ü. Mander and P. Jenssen (Eds.), Constructed Wetlands for Wastewater Treatment in Cold Climates, WIT Press, Southampton, UK. 